\title{
DOES THERE IS CONNECTION BETWEEN NITRITES IN URINE AND MOLES ON FACE?
}

Muhammad Imran Qadir,Baber Saeed and Izzah Fatima*

Institute of Molecular Biology and Biotechnology, Bahauddin Zakariya University, Multan, Pakistan.

\section{Email : izzahfatima000@gmail.com}

\begin{tabular}{|c|}
\hline ABSTRACT \\
\hline $\begin{array}{l}\text { The nearness of nitrites in pee is because of bacterial contamination in urinary tract. Urinary } \\
\text { tract disease can happen in urethra, kidneys, ureters and bladder. A few microscopic } \\
\text { organisms have capacity to change over the nitrates into nitrites because of essence of } \\
\text { explicit chemical. The nearness of nitrites in pee can be determined to have urinalysis test. } \\
\text { Moles may end up dim after introduction to the daylight amid the teenager years or } \\
\text { pregnancy. UV light that originates from the sun opens to moles and makes them } \\
\text { destructive. }\end{array}$ \\
\hline
\end{tabular}

Keywords: urine nitrite, urinary infection, skin pigments

\section{No: of Tables: 02}




\section{INTRODUCTION}

Nitrites is type of nitrogen, which comprises two oxygen particles. Nitrites is normally found in vegetables like cabbage, celery, carrot and spinach. The nearness of nitrites in pee might be destructive mean indication of urinary tract disease. The nearness of nitrites in pee is because of bacterial contamination in urinary tract. Urinary tract disease can happen in urethra, kidneys, ureters and bladder. A few microscopic organisms have capacity to change over the nitrates into nitrites because of essence of explicit chemical. The nearness of nitrites in pee can be determined to have urinalysis test. The microscopic organisms that are in charge of urinary tract contamination, proteus, klebsiella, pseudomonas. Be that as it may, most basic microbes is $E$. coli in which urease catalyst is available that ferments the pee. The manifestations of urinary tract contamination incorporate blood in pee, overcast pee, solid smelling pee and consuming with pee. Urinary tract contamination is most regular in pregnant ladies and might be risky. Urinary tract contamination can cause unexpected labor, migraine, stomach torment and hypertension in pregnant ladies whenever left untreated. In the event that test for the nitrites in pee is sure it is called nitrituria. While negative nitrites test occur with weaken pee or low state shaping unit. A urinary tract contamination is most normal in ladies matured 20 to 50 years than man. There are numerous ways that one can keeps from nitrites in pee or urinary tract contamination. For example, by drinking a lot of water microscopic organisms can be streak out that is available in urinary framework. Cranberry juice and apple juice vinegar additionally treat the urinary tract contamination. Specialist additionally recommended some medicine for the treatment of nitrites in pee. Specialist recommended anti-infection agents based on what sort of microscopic organisms cause contamination. Patient ought to likewise take enough rest and embrace individual hygiene.

Moles may end up dim after introduction to the daylight amid the teenager years or pregnancy. UV light that originates from the sun opens to moles and makes them destructive. The qualities that exchange from our folks alongside measure of sun introduction (amid adolescence) are real viewpoints in deciding quantities of moles. Moles happen when cells in the skin create in a gathering rather than being spread all through the skin. These pigments are called melanocytes, and they make the shade that gives skin its trademark shading. Moles may cloud after introduction to the sun, in the midst of the youthful years, and in the midst of pregnancy

\section{MATERIALS AND METHODS.}

For estimating the dimensions of nitrites in pee urinalysis is finished. Above all else, individual will require a vacant and clean plastic compartment so filled it with crisp example of pee. A strip and gloves are additionally required. By wearing the gloves dunked the new strip into holder and blended it into pee test for 2 seconds. The shade of strip will change than before as it will dunk into holder. Draw out strip 
from the example with the goal that deliberate the dimensions of nitrites into

pee. In the last dispose of the gloves, strip and

holder.

\section{RESULTS AND DISCUSSION}

Connection between moles on face and urine nitrites

\begin{tabular}{|l|l|l|l|l|}
\hline Moles on face & \multicolumn{2}{|l|}{ Men } & \multicolumn{2}{l|}{ Women } \\
\hline \multirow{3}{*}{ Nitrites in urine } & $\begin{array}{l}\text { Negative } \\
\text { standards }\end{array}$ & $\begin{array}{l}\text { Positive } \\
\text { standards }\end{array}$ & $\begin{array}{l}\text { Negative } \\
\text { standards }\end{array}$ & $\begin{array}{l}\text { Positive } \\
\text { standards }\end{array}$ \\
\cline { 2 - 5 } & $22 \%$ & $18 \%$ & $17 \%$ & $13 \%$ \\
\hline
\end{tabular}

This table displays that males have negative value of nitrites in their urine are $22 \%$ have moles on face and those who have positive value of nitrites are $18 \%$

have also moles on face. Similarly, females have negative value are $17 \%$ and females with positive value are $13 \%$ which have moles on face.

\section{Connection between moles on face and urine nitrites}

\begin{tabular}{|l|l|l|l|l|}
\hline $\begin{array}{l}\text { Having no moles } \\
\text { on face }\end{array}$ & Men & Women & \\
\hline \multirow{4}{*}{ Nitrites in urine } & $\begin{array}{l}\text { Negative } \\
\text { standards }\end{array}$ & $\begin{array}{l}\text { Positive } \\
\text { standards }\end{array}$ & $\begin{array}{l}\text { Negative } \\
\text { standards }\end{array}$ & $\begin{array}{l}\text { Positive } \\
\text { standards }\end{array}$ \\
\cline { 2 - 6 } & $11 \%$ & $10 \%$ & $5 \%$ & $4 \%$ \\
\hline
\end{tabular}

This table displays that males with negative values are $11 \%$ and with positive values are only $10 \%$ All of these males having no moles on face. Similarly, females having negative values are $5 \%$ have no moles on face. While females having positive value of nitrites in their urine are just $4 \%$ having no moles on face.

\section{Conclusion}

This was decided that there is no relevancy between urine nitrites and moles on face. 